\title{
PENERAPAN STRATEGI SQ3R DALAM PEMBELAJARAN MEMBACA KRITIS SASTRA (CERPEN) PADA SISWA MI KELAS LANJUT
}

\author{
M. Zubad Nurul Yaqin \\ Dosen Tetap Fakultas Humaniora dan Budaya UIN Maulana Malik Ibrahim Malang
}

\begin{abstract}
Learning of reading literature (in this concerning short story) in formal education scope (as in Islamic elementary school, especially at advanced grade) wasn't maximal yet. In objective condition, learning of reading short story at advanced grade, generally still definite in structure analyzing, didn't administer in activities that able to train students in reading and appraising literature critically. Thus, learning activities by applying some strategy to achieve learning objectives need to do. Some strategy which can be used are SQ3R strategy.SQ3R strategy is one of strategy in learning of reading to help reader understand whole and detail about content of the text. By using SQ3R strategy, reader (students) will be faster to find mind idea in the text. Steps of SQ3R application are survey, question, read, recite, dan review. To achieve learning objectives maximally, that steps should be apllied systematically.
\end{abstract}

Keyword: SQ3R Strategy, critical reading, students of Islamic elementary school, advanced class

\section{A. Pendahuluan}

Fungsi pembelajaran bahasa Indonesia di sekolah-sekolah (termasuk di MI) adalah untuk meningkatkan kemampuan siswa dalam berkomunikasi dengan menggunakan bahasa Indonesia (baik lisan maupun tulis), menajamkan kepekaan perasaan, dan meningkatkan kemampuan di dalam mendapatkan wawasan atau informasi. Dengan kemampuan tersebut, siswa diharapkan mampu memahami informasi yang disampaikan, baik secara lugas maupun terselubung (Depdikbud, 1993). Adapun di dalam kurikulum 1994 SD (Sekolah Dasar), dinyatakan bahwa fungsi pembelajaran bahasa Indonesia adalah (1) sebagai sarana peningkatan pengetahuan dan keterampilan dalam rangka pelestarian dan pengembangan budaya; (2) sebagai sarana peningkatan pengetahuan dan keterampilan untuk meraih dan mengembangkan berbagai ilmu pengetahuan, teknologi, dan seni; serta (3) sebagai sarana penyebarluasan pemakaian bahasa dan sastra Indonesia. Berbagai kemampuan yang diharapkan dalam pembelajaran berbahasa tersebut dilatihkan pada siswa melalui empat aspek keterampilan berbahasa, yakni: membaca, menyimak, berbicara, dan menulis. 


\section{Zubad Nurul Yaqin- Penerapan Strategi SQ3R dalam Pembelajaran Membaca Kritis Sastra (Cerpen) pada Siswa MI Kelas Lanjut}

Membaca merupakan salah satu aspek keterampilan berbahasa yang memiliki kedudukan penting dan strategis. Dikatakan demikian karena membaca merupakan bagian dari hidup manusia. Hal ini sejalan dengan pernyataan Burns (1996:5), bahwa setiap aspek kehidupan ini keberadaannya tidak bisa dilepaskan dari respon yang berupa kegiatan membaca. Atau, semua yang ada di sekitar manusia (khususnya yang berbentuk tulisan) hanya dapat dipahami karena adanya proses membaca. Oleh karena itu, cukup beralasan apabila Syafi' ie (1993:25) menyatakan bahwa keterampilan membaca tidak hanya dibutuhkan oleh masyarakat akademis, akan tetapi juga diperlukan oleh siapa saja yang membutuhkan informasi (khususnya dari media cetak). Singkatnya, sudah sewajarnya apabila membaca telah menjadi kebutuhan dan bagian dari gaya hidup masyarakat.

Membaca merupakan sebuah bentuk keterampilan. Dalam konteks pembelajaran, seseorang (siswa) dikatakan terampil membaca apabila ia dapat memahami makna yang terdapat di dalam bacaan. Untuk memenuhi hal tersebut, siswa harus dilatih membaca secara terus-menerus, tentunya dengan berbagai strategi membaca yang sesuai dengan kebutuhan siswa. Oleh karena itu, dalam pembelajarannya guru harus mampu mengarahkan siswa agar dapat memilih dan menggunakan strategi membaca yang efektif dalam rangka mendapatkan pemahaman isi bacaan yang sedang dibaca tersebut.

Pembelajaran membaca di sekolah mimiliki peran penting dalam membantu siswa agar terampil membaca. Terampil membaca bukan hanya sekadar dapat membaca kata-kata, tetapi juga dapat membuat siswa menjadi mahir wacana (kemahirwacanaan), yakni mahir secara tekstual maupun kontekstual (Tompskin dan Hoskisson, 1991:18). Singkatnya, siswa dikatakan terampil (mahir) membaca apabila ia (1) mampu mencari, menyerap, dan menyeleksi informasi yang relevan secara cepat dan tepat, serta (2) mampu memanfaatkan kompetensi yang dimiliki tersebut dalam mendukung pandangan, merespon beragam teks dan menggunakannya untuk membuat intervensi dan deduksi (Depdiknas, 2003:4).

Sehubungan dengan pembelajaran membaca pemahaman (kritis), guru harus mampu menerapkan strategi mengajar yang sesuai dengan kebutuhan siswa. Oleh karena itu, sebelum menentukan strategi pembelajaran membaca, terlebih dahulu guru harus memahami tingkatan-tingkatan membaca pemahaman atau tipe-tipe pemahaman teks bacaan. Sehubungan dengan hal ini, Smith (dalam Robin, 1993:195), 
menyatakan bahwa ada beberapa tipe pemahaman, yakni pemahaman literal (literal comprehension), pemahaman interpretatif (interpretative comprehension), pemahaman kritis (critical comprehension), dan pemahaman kreatif (creative comprehension). Keempat tipe pemahaman tersebut saling berkaitan.

Membaca pemahaman (kritis) merupakan salah satu tingkatan membaca yang mimiliki kedudukan strategis dalam pembelajaran bahasa Indonesia (termasuk juga di MI) . Membaca kritis perlu diajarkan kepada siswa, karena pada prinsipnya para siswa tidak hanya ingin mengetahui apa yang dibaca, melainkan juga ingin mengetahui kebenaran suatu informasi yang ada pada teks bacaan. Menurut Burns (1996:278), membaca kritis merupakan kegiatan mengevaluasi materi tertulis, yakni membandingkan gagasan yang tercakup dalam materi dengan standar yang diketahui dan menyimpulkan tentang keakuratan atau kesesuaiannya. Jadi, pembaca kritis harus bisa menjadi pembaca yang aktif (bertanya, meniliti fakta-fakta, mempertimbangkan semua isi materi, dsb.). Membaca kritis merupakan kegiatan yang dimulai dari kegiatan analisis, sintesis, dan evaluasi. Atau, membaca kritis lebih tepat dikatakan sebagai membaca analisis dan evaluasi. Oleh karena itu, seorang pembaca kritis harus mimiliki pikiran yang tajam sehingga mampu bersikap kritis terhadap teks yang dibaca (Harris dan Smits, 1986:302).

Sampai saat ini, kondisi objektif pembelajaran membaca sastra (cerpen) di lembaga pendidikan formal masih belum optimal. Dikatakan demikian karena pembelajaran membaca cerpen pada umumnya masih terbatas pada analisis struktur cerpen dengan menekankan pada aspek kognitif semata. Dalam hal ini, kegiatan yang dilakukan biasanya dimulai dengan kegiatan membaca dan diakhiri dengan menganalisis unsur instrinsik cerpen. Padahal, kegiatan tersebut sebenarnya dapat diarahkan pada upaya melatih siswa untuk memberikan penilaian secara kritis dengan melibatkan berbagai kemampuan, kepekaan emosi, dsb.). Dengan perkataan lain, analisis struktur yang selama ini selalu diberlakukan dalam pembelajaran membaca cerpen kurang memberikan kesempatan kepada siswa untuk berinteraksi dan mengakrabkan diri dengan cerpen.

Pembelajaran membaca kritis sastra (cerpen) sampai saat ini tampak belum optimal, baik ditinjau dari segi tahap perencanaan, tahap pelaksanaan, maupun tahap evaluasi pembelajaran. Pada tahap perencanaan (khususnya dalam memilih bahan cerpen), guru tampak masih mengalami kesulitan dalam menentukan materi yang 
menarik dan sesuai dengan tingkat kemampuan siswa. Guru umumnya mengambil materi pembelajaran cerpen dari buku paket (tidak membuat cerpen sendiri yang lebih sesuai dengan kebutuhan dan kondisi siswa). Pada tahap pelaksanaan, guru seringkali menggunakan strategi pembelajaran membaca yang kurang tepat dan kurang bervariasi. Dalam hal ini, kegiatan guru biasanya sebatas pada memilih bahan cerpen dan menyuruh siswa untuk membacanya. Setelah membaca siswa disuruh menjawab pertanyaan yang berhubungan dengan cerpen tersebut. Ironisnya lagi, guru tidak membantu atau membimbing siswa dalam membaca pada saat kegiatan pembelajaran membaca berlangsung cerpen. Guru lebih sibuk dengan dirinya sendiri. Pada tahap evaluasi, umumnya guru hanya mengambil nilai dari hasil menjawab pertanyaan cerpen tanpa melihat proses membaca yang dilakukan oleh siswa. Apabila kondisi tersebut terus berlanjut, maka siswa kan kurang terlatih untuk berpikir kritis karena kehiatan belajar-mengajar siswa hanya hanya berkutat pada unsur-unsur literal yang terdapat dalam cerpen. Kondisi seperti ini tentu memprihatinkan.

Bertumpu pada berbagai hal yang telah diuraikan di atas, sebagai upaya untuk mengoptimalkan pembelajaran membaca kritis cerpen, sudah sepatutnya apabila praktik pembelajaran dilakukan dengan memanfaatkan berbagai strategi, tentunya strategi pembelajaran yang memungkinkan tercapainya tujuan pembelajaran yang diharapkan. Strategi yang dimaksud, antara lain adalah Strategi SQ3R. Agar diperoleh gambaran yang menyeluruh tentang permasalahan yang diajukan, maka dalam tulisan ini akan disajikan secara berturut turut konsep-konsep tentang hakikat membaca kritis (membaca pemahaman), pembelajaran membaca pemahaman di sekolah dasar (SD/MI), dan penerapan strategi SQ3R di MI kelas Lanjut.

\section{B. Hakikat Membaca Kritis (Pemahaman)}

Aspek-aspek keterampilan berbahasa di dalam pembelajaran bahasa dan sastra Indonesia dapat dilaksanakan secara terpadu. Artinya, pembelajaran keterampilan berbahasa (misalnya keterampilan membaca) dapat dipadukan dengan keterampilan menyimak, berbicara, dan keterampilan menulis. Begitulah seterusnya. Dengan perkataan lain, di dalam setiap pembelajaran kebahasaan secara tidak langsung akan tercermin semua aspek keterampilan berbahasa yang meliputinya, meskipun pelajarannya hanya difokuskan pada salah satu aspek. Selain itu, keterpaduan yang dimaksud bukan berarti bahwa semua komponen yang terdapat di dalam setiap aspek 
keterampilan berbahasa tersebut (misalnya komponen pemahaman, komponen kebahasaan) harus ditonjolkan. Akan tetapi, salah satu komponen saja yang harus ditonjolkan.

Salah satu kegiatan pembelajaran yang terkait dengan komponen pemahaman adalah pembelajaran membaca. Membaca merupakan salah satu keterampilan berbahasa yang bersifat aktif-reseptif, yakni proses penyerapan informasi yang dilakukan secara aktif. Dikatakan aktif karena selain mengandalkan mata sebagai sarana utama dalam menerjemahkan lambang-lambang huruf (tulisan), proses membaca juga melibatkan berbagai piranti lainnya yang terdapat di dalam diri seseorang (seperti pengetahuan seseorang yang berhubungan dengan topik). Selain itu, pembaca akan berupaya agar lambang-lambang yang dilihatnya itu menjadi lambang-lambang yang bermakna baginya.

Membaca pada prinsipnya merupakan proses berpikir konstrutif yang mencakup pemahaman terhadap makna eksplisit dan implisit. Menurut Strauffer dan Walker (Pamfrey, 1977: 2), proses membaca di dalamnya melibatkan aplikasi, analisis, evaluasi dan imajinasi. Berdasarkan pendapat tersebut, tampak bahwa membaca merupakan proses berpikir untuk mendapatkan pesan yang disampaikan penulis melalui tulisannya. Adapun untuk mendapatkan pesan dari bahan bacaan, seseorang diharapkan mampu membaca dengan baik sehingga pesan atau informasi yang disampaikan penulisnya dapat dipahami dengan baik pula. Dengan demikian, dapat dikatakan bahwa keterampilan membaca bukan hanya merupakan salah satu keterampilan dasar untuk menunjang keberhasilan dalam mengikuti pendidikan dan pengajaran di sekolah, melainkan juga merupakan keterampilan yang sangat penting bagi setiap orang dalam kehidupan di masyarakat.

Kenyataan yang sering ditemukan dalam konteks pembelajaran membaca (diantaranya di MI kelas lanjut), biasanya siswa ditugasi membaca sebuah teks beberapa menit, selanjutnya siswa diminta untuk menjawab berbagai pertanyaan yang berhubungan dengan bacaan tersebut. Jadi, dalam hal ini kegiatan membaca tidak diawali dengan tahap prabaca atau tahap menggali skemata siswa, hanya mengutamakan kegiatan pascabaca yang diarahkan pada penilaian akhir pembelajaran. Kondisi seperti ini tentunya berimplikasi pada rendahnya tingkat kemampuan siswa dalam memahami isi bacaan. Sehubungan dengan hal ini, salah satu cara yang dapat ditempuh agar siswa dapat dengan lebih mudah dalam 
memahami isi bacaan adalah dengan cara membangkitkan kembali pengalaman siswa yang berhubungan dengan topik bacaan. Pengalaman siswa yang berkaitan dengan isi bacaan dapat menentukan tingkat atau level pemahaman dalam membaca. Semakin banyak pengalaman siswa yang berkaitan dengan isi bacaan, maka akan semakin tinggi pula tingkat pemahaman dalam membacanya.

Khusus sehubungan dengan tingkat pemahaman dalam membaca, Burns menyatakan bahwa terdapat dua tipe pemahaman dalam membaca, yakni pemahaman tingkat dasar (literal comprehension) dan pemahaman tingkat tinggi (higher order comprehenship). Membaca pemahaman tingkat tinggi meliputi membaca interpretative (interpretative reading), membaca kritis (critical reading), dan membaca kreatif (creative reading). Keberadaan kedua tipe membaca pemahaman tersebut saling berkaitan antara satu dengan yang lainnya. Karena keduanya tipe tersebut merupakan dasar didalam melaksanakan pembelajaran membaca pemahaman, maka guru harus memahaminya. Pemahaman literal menjadi dasar untuk pemahan yang lebih tinggi, begitu juga sebaliknya (Burns , 1996:255).

Sehubungan dengan hal tersebut, perlu dipahami pula bahwa membaca pemahaman merupakan sebuah proses. Oleh karena itu, sebelum menentukan langkah-langkah proses pembelajaran membaca, guru seharusnya mengetahui dan memahami kondisi siswa (misalnya tingkat kecerdasan, kreatifitas, kondisi fisik, kebutuhan, perkembangan kognitif). Singkatnya, untuk mendorong siswa dalam membaca pemahaman, hendaknya para guru memperhatikan faktor-faktor yang berkaitan erat dengan kebutuhan siswa sehingga ia akan melakukan proses membaca pemahaman dengan penuh kesungguhan.

Sebagai tambahan terkait dengan uraian di atas, Stern menyatakan bahawa pertumbuhan dan perkembangan manusia dapat diklasifikasikan atas aspek kognitif, psikologis, dan fisik. Adapun pertumbuhan dan perkembangan manusia tersebut berhubungan dengan perubahan struktur dan fungsi karakteristik manusia itu sendiri. Perubahan-perubahan tersebut terjadi dalam kemajuan yang mantap dan merupakan suatu proses kematangan. Perubahan tersebut tidak bersifat umum, melainkan merupakan hasil interaksi antara potensi bawahan dengan potensi lingkungan. Guru juga harus memahami kondisi tersebut (Mulyasa, 2004: 125).

Mulyasa menyatakan bahwa tantangan bagi pendidikan adalah mengupayakan bagaimana menemukan atau menciptakan metode pendidikan dan 
lingkungan-lingkungan yang sesuai dengan kebutuhan setiap individu (siswa) yang unik tersebut. Secara khusus apabila dikaitkan dengan konteks pembelajaran membaca pemahaman, penyebab timbulnya permasalahan yang dialami siswa dalam memahami isi bacaan tersebut diduga sebagai akibat dari pelaksanaan pembelajaran yang masih menggunakan strategi pembelajaran yang konvesional. Di dalam pembelajaran konvesional, guru kurang membangkitkan skemata siswa sebelum membaca. Dikatakan demikian karena ketika disajikan suatu bahan bacaan, siswa tidak melakukan dan tidak dapat memahami dengan baik kegiatan prabaca (berkaitan dengan curah pendapat tentang topik yang akan dibaca). Oleh karena itu, siswa tidak memiliki pengetahuan awal yang dapat membantu memahami isi bacaan tersebut. Kegiatan prabaca lebih banyak diarahkan pada penjelasan tentang apa yang harus dilakukan siswa setelah membaca teks (Mulyasa, 2004: 125).

\section{Pembelajaran Membaca Pemahaman di Sekolah Dasar (SD/MI)}

Pembelajaran membaca pemahaman di tingkat Sekolah Dasar (dalam hal ini MI) seharusnya diberikan pada siswa MI kelas lanjut. Dikatakan demikian karena siswa MI kelas lanjut di dalam dirinya sudah memungkinkan untuk berbagai tahapan operasional yang mengarah pada kegiatan berpikir formal dan abstrak. Pada tingkat MI kelas lanjut, siswa sudah mampu menganalisis dan memahami ide-ide, mampu berpikir logis tentang data-data yang abstrak, mampu menyusun hipotesis, serta mampu membangun konsep-konsep sederhana mengenai berbagai hal yang dipelajarinya.

Sehubungan dengan hal tersebut, perlu dipahami bahwa tahap pelaksanaan pembelajaran membaca pemahaman harus diawali dengan kegiatan pengelompokan dan klasifikasi tentang kondisi siswa yang pada kenyataannya memang mimiliki kemampuan dan daya serap yang berbeda sesuai dengan potensi dasar yang dimilikinya. Di dalam Kurikulum Berbasis Kompetensi, dinyatakan bahwa perbedaan individu dapat diklasifikasikan menjadi tiga kelompok, yaitu: normal, sedang, dan kelompok tinggi. Tujuan diversifikasi tentang pengembangan siswa (siswa) pada masing-masing kelompok di dalam kurikulum tersebut adalah (1) untuk kelompok normal: mengembangkan pemahaman tentang prinsip dan praktik aplikasi serta mengembangkan kemampuan praktik akademik yang berhubungan dengan kemampuan kerja, (2) untuk kelompok sedang: mengembangkan berbagai kemahiran 
(kemahiran berkomunikasi, kemahiran potensi diri, aplikasi praktik, kemahiran akademik, dan kemahiran praktik yang berhubungan dengan tuntutan dunia kerja ataupun demi kelanjutan program pendidikan professional; serta (3) untuk kelompok tinggi: mengembangkan pemahaman tentang prinsip, teori, aplikasi, dan mengembangkan kemampuan akademik untuk memasuki pendidikan tinggi.

\section{Penerapan Strategi SQ3R dalam Pembelajaran Membaca Pemahaman (Kritis) Sastra (Cerpen) di MI Kelas Lanjut}

Bertumpu pada berbagai uraian di atas, tampak bahwa pemberian motivasi terhadap siswa dalam pembelajaran membaca pemahaman di kalangan siswa MI kelas lanjut merupakan sebuah tantangan tersendiri bagi kalangan dunia pendidikan, khususnya bagi guru. Oleh karena itu, sudah sewajarnya apabila para guru diharapkan mampu menemukan format dan pola pembelajaran Bahasa dan Sastra Indonesia yang lebih baru, menarik, dan menyenangkan agar pembelajaran dapat berlangsung kondusif. Apabila kondisi tersebut dapat terwujud, maka tidak mustahil para siswa akan semakin cinta dan bangga terhadap bahasa Indonesia.

Sebagai salah satu upaya untuk menemukan model pembelajaran Bahasa dan Sastra Indonesia yang terkait dengan kompetensi belajar membaca, maka penulis tertarik mengkaji ulang tentang penerapan strategi SQ3R untuk meningkatkan kemampuan membaca pemahaman (kritis) siswa (dalam hal ini membaca kritis sastra [cerpen] yang difokuskan pada siswa MI kelas lanjut.

Strategi SQ3R merupakan strategi pembelajaran membaca yang bertujuan untuk membantu pembaca agar dapat memahami secara utuh dan rinci tentang isi suatu teks. Dengan Strategi SQ3R, pembaca akan lebih cepat menemukan gagasangagasan pokok yang terdapat di dalam teks. Langkah-langkah yang terdapat di dalam Strategi SQ3R, meliputi: survey, question, read, recite, dan review. Langkah-langkah tersebut harus diterapkan secara berurutan agar tujuan yang ingin dicapai dalam membaca dapat tercapai (Eanes, 1997:5-82). Masing-masing tahapan tersebut diuraikan sebagai berikut.

1. Tahap pengamatan (survey). Pada tahap ini siswa dituntut dapat menafsirkan makna judul cerpen, mengetahui biografi penulis, mengidentifikasi kata apa yang dipakai untuk membahasakan diri penulis dalam cerpen, mengidentifikasi sudut pandang tokoh dalam penceritaan, 
menyebutkan tokoh-tokoh yang terlibat, dan menentukan peristiwa (awal, tengah, dan akhir) dari cerpen secara sekilas.

2. Tahap menyusun pertanyaan (question). Pada tahap ini siswa diminta membuat pertanyaan-pertanyaan yang berhubungan dengan menggunakan konsep pertanyaan $5 \mathrm{~W}+1 \mathrm{H}$.

3. Tahap membaca (read). Pada tahap ini kegiatan siswa adalah membaca dalam hati cerpen secara keseluruhan dan menandai bagian-bagian cerpen yang menjadi jawaban atas pertanyaan yang telah dibuat. Sebagai tambahan, pada tahap ini sebenarnya terjadi tahap record, yakni siswa dituntut dapat mengidentifikasi tokoh dan penokohan cerpen, mengidentifikasi latar atau setting cerpen, mengidentifikasi plot (alur) cerpen, mengidentifikasi nilai-nilai cerpen, dan menentukan.tema cerpen.

4. Tahap menceritakan kembali (recite), yakni siswa menceritakan kembali isi cerpen secara keseluruhan dengan menggunakan kata-kata sendiri.

5. Tahap pembelajaran yang terakhir adalah memeriksa atau meninjau ulang (review). Pada tahap ini siswa diminta untuk memeriksa dan meninjau kembali benar tidaknya catatan-catatan penting (terkait dengan isi cerpen) yang telah dibuatnya. Jika belum, maka siswa harus mencatat kembali, kemudian mengkaji kembali pekerjaan itu secara benar.

Kegiatan di atas bersifat menyeluruh. Dikatakan demikian karena di dalam pembelajaran membaca pemahaman sastra dengan Strategi SQ3R, siswa diharapkan mampu mengingat kembali isi cerpen yang telah dibacanya secara keseluruhan. Apabila siswa tidak mampu melakukannya, maka siswa harus membaca kembali dengan teliti catatan-catatan yang telah dibuatnya tentang isi cerpen tersebut. Hal ini dilaksanakan agar siswa mampu mengomentari cerpen yang telah dibacanya.

Berdasarkan sedikit ilustrasi tersebut, tampak bahwa Strategi SQ3R dalam pembelajaran membaca kritis cerpen memang diperlukan. Dengan Strategi SQ3R, siswa memiliki kebebasan dalam menganalisis cerpen, siswa terangsang untuk mampu berpikir kritis terhadap permasalahan di sekitarnya, melatih siswa untuk belajar secara kolaboratif, dan kemampuan siswa diukur berdasarkan hasil karya dan unjuk kerja .

Sebagai tambahan, perlu dipahami bahwa pembelajaran membaca di sekolah dasar merupakan salah satu pembelajaran yang esensial. Sebagai contoh, di dalam GBPP 1994, dinyatakan bahwa tujuan pelajaran membaca untuk kelas enam (kelas 
lanjut), adalah: siswa memahami isi wacana secara garis besar dan memberikan tanggapan dalam berbagai bentuk, siswa mampu mengungkapkan sendiri sesuatu yang dibaca dan didengar, siswa mampu mendapatkan informasi dari berbagai bahan tertulis atau lisan (pengetahuan, gagasan, pendapat, permasalahan, pesan, ungkapan perasaan, pengalaman dan peristiwa), siswa mampu memberikan tanggapan dalam berbagai bentuk, serta siswa mampu mendapatkan data maupun fakta dari buku-buku dan memanfaatkannya untuk berbagai keperluan (Depdikbud, 1993:4). Sebagai upaya untuk mencapai tujuan tersebut, sebelumnya guru dituntut mampu memahami prinsip-prinsip membaca dan cara mengajarkannya kepada siswa.

Fakta-fakta tentang rendahnya kemampuan siswa di dalam memahami isi bacaan (cerpen) antara lain diduga disebabkan oleh kurang tepatnya strategi pembelajaran yang dipilih dan diterapkan oleh guru, dalam hal ini khususnya strategi pembelajaran membaca pemahaman sastra. Dengan perkataan lain, guru kurang memiliki kemampuan untuk melakukan inovasi dalam pembelajaran. Sebab utamanya adalah guru kurang memiliki pengetahuan dan kurangnya pemahaman tentang berbagai strategi pembelajaran (diantaranya strategi pembelajaran membaca kritis). Sehubungan dengan hal ini, Strategi SQ3R merupakan salah satu strategi dalam membaca yang bertujuan untuk membantu pembaca untuk memahami secara utuh dan rinci tentang isi suatu teks. Singkatnya, dengan strategi SQ3R pembaca akan lebih cepat menemukan gagasan-gagasan pokok yang ada dalam teks. (Eanes, 1997:5-82).

. Selanjutnya, agar mendapat gambaran lebih konkret mengenai penerapan strategi SQ3R yang dimaksud, berikut ini akan disajikan contoh-contoh panduan analisis kebutuhan pembelajaran dengan mengacu pada penerapan Strategi SQ3R, baik pada tahap sebelum pelaksanaan pembelajaran, maupun pada tahap saat pelaksanaan. Masing-masing digambarkan seperti pada tabel berikut.

Contoh analisis sebelum pelaksanaan pembelajaran dengan strategi SQ3R

\begin{tabular}{|c|c|c|}
\hline No & $\begin{array}{c}\text { Aspek Yang } \\
\text { Diidentifikasikan }\end{array}$ & Langkah-Langkah \\
\hline $\begin{array}{l}1 . \\
2 .\end{array}$ & $\begin{array}{l}\text { Merumuskan tujuan } \\
\text { pembelajaran. } \\
\text { Memilih materi } \\
\text { pelajaran. }\end{array}$ & $\begin{array}{l}\text { - Menentukan rumusan Tujuan Pembelajaran Khusus } \\
\text { (TPK). } \\
\text { - Menentukan materi pembelajaran yang sesuai dengan } \\
\text { kebutuhan siswa (sesuai, menarik, dan dapat } \\
\text { merangsang minat belajar siswa). }\end{array}$ \\
\hline
\end{tabular}




\begin{tabular}{|l|l|l|}
\hline 4. & $\begin{array}{l}\text { Merencanakan dan } \\
\text { menetapkan jenis } \\
\text { pembelajaran. }\end{array}$ & - Menentukan jenis pembelajaran yang diinginkan. \\
5. & $\begin{array}{l}\text { Kegiatan Belajar } \\
\text { Mengajar (KBM). }\end{array}$ & $\begin{array}{l}\text { - Menentukan langkah-langkah pembelajaran. } \\
\text { dengan materi dan rumusan tujuan pembelajaran }\end{array}$ \\
6. & $\begin{array}{l}\text { Memilih media dan } \\
\text { sumber belajar. }\end{array}$ & $\begin{array}{l}\text { yang akan dicapai } \\
\text { - Mengembangkan dan mengorganisasikan materi } \\
\text { pembelajaran. }\end{array}$ \\
& $\begin{array}{l}\text { - Merencanakan dan menyiapkan instrumen penilaian. } \\
\text { Merencanakan } \\
\text { evaluasi/penilaian. }\end{array}$ & Menentukan indikator dan kriteria penilaian. \\
\hline
\end{tabular}

Contoh analisis pelaksanaan pembelajaran dari aspek guru

\begin{tabular}{|c|c|c|}
\hline $\begin{array}{c}\text { Tahap } \\
\text { pembelajaran }\end{array}$ & Aspek & Langkah-Langkah \\
\hline Survey & $\begin{array}{l}\text { Guru membuka } \\
\text { pelajaran. } \\
\text { Guru } \\
\text { membangkitkan } \\
\text { skemata siswa } \\
\text { terkait dengan } \\
\text { bahan bacaan. } \\
\\
\text { Guru } \\
\text { memrediksi isi } \\
\text { bacaan. }\end{array}$ & $\begin{array}{l}\text { - Menyampaikan tujuan pembelajaran. } \\
\text { - Menjelaskan tugas-tugas belajar. } \\
\text { - Membagi tugas dalam kelompok. } \\
\text { - Curah pendapat untuk membangkitkan } \\
\text { skemata siswa. } \\
\text { - Menampilkan gambar dan topik cerpen dan } \\
\text { meminta siswa untuk menuliskan } \\
\text { pengetahuan yang dimiliki yang } \\
\text { berhubungan dengan gambar dan topik } \\
\text { cerpen tersebut. } \\
\text { - Meminta siswa untuk mengidentifikasi sudut } \\
\text { pandang tokoh dalam penceritaan cerpen. } \\
\text { - Memprediksi isi cerpen berdasarkan gambar } \\
\text { dan topik yag ditampilkan guru. }\end{array}$ \\
\hline Question & $\begin{array}{l}\text { Guru } \\
\text { membimbing } \\
\text { siswa membuat } \\
\text { pertanyaan } \\
\text { tentang apa } \\
\text { yang ingin } \\
\text { diketahui dari } \\
\text { cerpen. }\end{array}$ & $\begin{array}{l}\text { - Membimbing siswa untuk memprediksi isi } \\
\text { cerpen dalam bentuk kalimat tanya. } \\
\text { - Meminta siswa untuk menuliskan informasi } \\
\text { yang diketahuinya pada kolom record. }\end{array}$ \\
\hline
\end{tabular}




\begin{tabular}{|c|c|c|}
\hline & $\begin{array}{l}\text { Guru } \\
\text { mengarahkan } \\
\text { siswa membaca } \\
\text { dalam hati dan } \\
\text { mengerjakan } \\
\text { tugas. }\end{array}$ & $\begin{array}{l}\text { - Membagikan teks bacaan dan lembar kerja } \\
\text { siswa. } \\
\text { - Meminta siswa membaca dalam hati. } \\
\text { - Memberi bimbingan pada siswa dalam } \\
\text { mengerjakan tugas dan menjawab } \\
\text { pertanyaan-pertanyaan yang ditulisnya pada } \\
\text { kolom record. }\end{array}$ \\
\hline Read E Record & $\begin{array}{l}\text { Guru } \\
\text { membimbing } \\
\text { siswa untuk } \\
\text { menuliskan hal- } \\
\text { hal penting } \\
\text { tentang isi } \\
\text { cerpen. }\end{array}$ & $\begin{array}{l}\text { - Membimbing siswa untuk menuliskan } \\
\text { informasi yang telah diperolehnya dari } \\
\text { membaca. } \\
\text { - Membimbing siswa untuk memetakan } \\
\text { informasi yang telah diperolehnya. } \\
\text { - Meminta siswa untuk memeriksa kembali } \\
\text { pertanyaan-pertanyaan yang telah dituliskan } \\
\text { pada kolom record, apakah sudah terjawab. } \\
\text { - Meminta siswa membuat kesimpulan. }\end{array}$ \\
\hline Recite & $\begin{array}{l}\text { Guru meminta } \\
\text { siswa } \\
\text { menceritakan } \\
\text { kembali isi } \\
\text { cerpen dengan } \\
\text { kata-kata } \\
\text { sendiri. }\end{array}$ & $\begin{array}{l}\text { - Meminta siswa untuk mempresentasikan } \\
\text { hasil kerja kelompoknya. } \\
\text { - Meminta siswa untuk menanggapi hasil } \\
\text { presentasi kelompok lain }\end{array}$ \\
\hline Review & $\begin{array}{l}\text { Guru } \\
\text { memantapkan } \\
\text { pemahaman } \\
\text { terhadap } \\
\text { cerpen. }\end{array}$ & $\begin{array}{l}\text { - Mengadakan refleksi untuk memantapkan } \\
\text { pemahaman siswa terhadap materi yang telah } \\
\text { dipelajarinya. } \\
\text { - Memberi evaluasi hasil dan memberikan PR. }\end{array}$ \\
\hline
\end{tabular}


Contoh analisis pelaksanaan pembelajaran dari aspek siswa

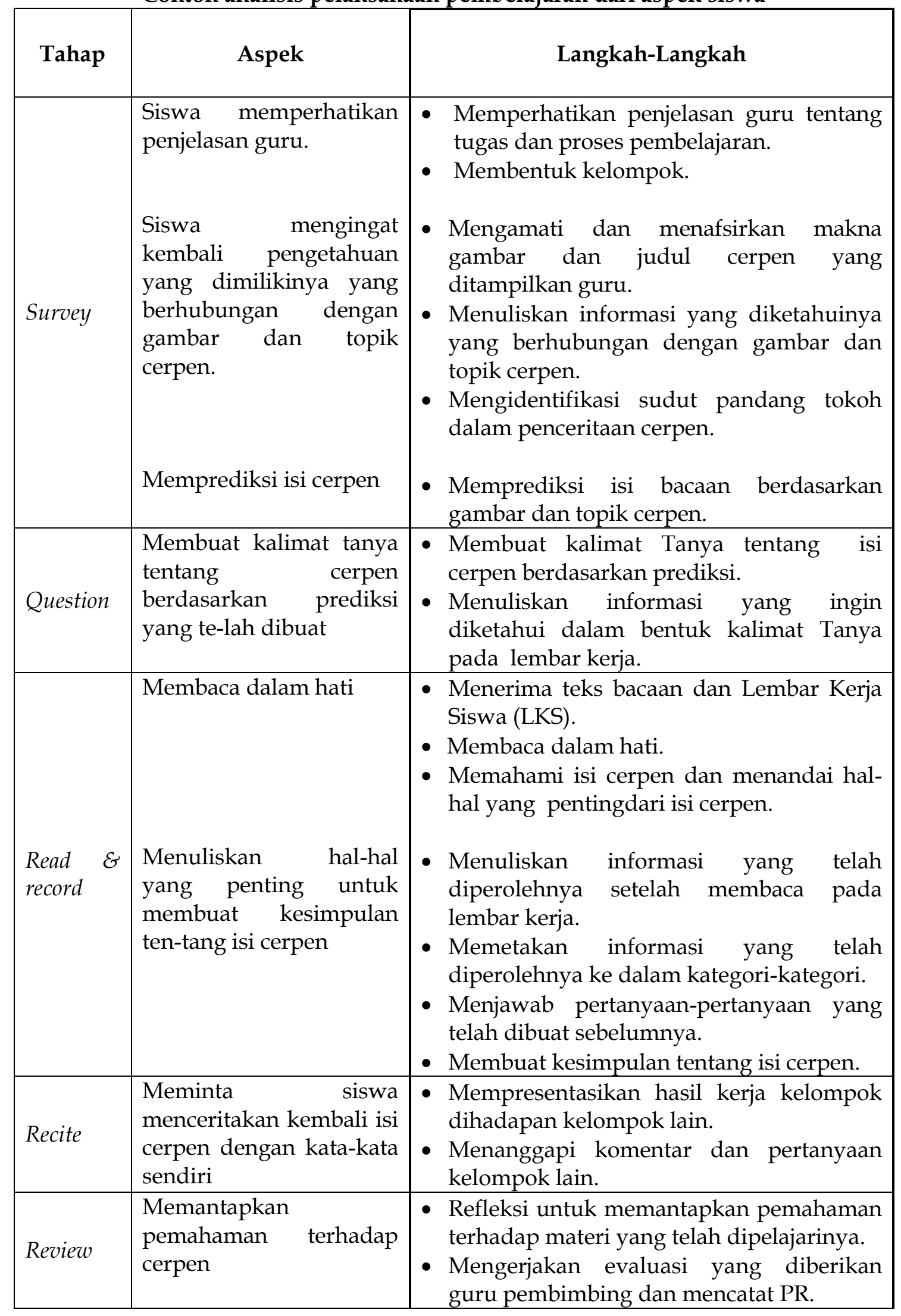


Demikianlah sedikit gambaran tentang penerapan strategi SQ3R dalam pembelajaran membaca kritis sastra (cerpen). Perlu juga diuraikan di sini, SQ3R hanyalah merupakan salah satu strategi alternatif dalam pembelajaran membaca. Dengan demikian, tentunya strategi ini bukan satu-satunya strategi yang paling tepat digunakan dalam pembelajaran (khususnya pembelajaran membaca). Dikatakan demikian karena keberhasilan suatu pembelajaran disebabkan oleh banyak faktor.

\section{E. Penutup}

Berdasarkan uraian tentang penerapan strategi SQ3R dalam membaca kritis sastra (cerpen) di atas, dapat disimpulkan beberapa poin penting sebagai berikut.

1. Sebagai upaya untuk mencapai tujuan dari proses pembelajaran membaca pemahaman, siswa guru perlu membuat perencanaan proses pembelajaran. Hal tersebut perlu dilakukan agar pelaksanaan pembelajaran membaca pemahaman siswa dapat berjalan lebih terarah.

2. Dalam upaya meningkatkan kemampuan membaca kritis cerpen dalam pembelajaran membaca pemahaman siswa, guru perlu menjelaskan terlebih dahulu tentang tujuan pembelajaran, membangkitkan skemata siswa yang bekaitan dengan topik cerpen, membimbing siswa dalam proses menemukan pokok pikiran dalam cerpen, memantapkan pemahaman siswa terhadap bahan bacaan dan mengadakan evaluasi.

3. Penerapan Strategi SQ3R dalam pembelajaran membaca pemahaman dapat meningkatkan kemampuan siswa dalam membaca kritis (diantaranya dalam membaca cerpen)

4. Penerapan starategi pembelajaran yang dilandasi dengan pengkajian secara ilmiah akan dapat membangkitkan skemata pemikiran siswa sehingga dapat menunjang ketercapaian tujuan dan ketuntasan belajar.

5. SQ3R merupakan strategi belajar yang efektif, namun ini tidak berlaku bagi semua siswa. Karenanya, pengenalan terhadap beragam variasi strategi merupakan hal penting bagi siswa, yakni pengenalan berbagai strategi yang dapat mengembangkan kesadaran metakognisi mereka.

\section{F. Daftar Pustaka}

Burns, Paul C. Betty D. Roe Elinor P. Ross. (1996). Teaching Reading in Today's Elementary Schools. Boston: Houghton Mifflin Company 


\section{Zubad Nurul Yaqin- Penerapan Strategi SQ3R dalam Pembelajaran Membaca Kritis Sastra (Cerpen) pada Siswa MI Kelas Lanjut}

De Porter, Bobbi \& Mike Hernacki. (1992). Quantum Learning :UnleashingThe Genius In You. New York .Dell Publishing.

Depdikbud. (1993). Kurikilum: Garis-garis Besar Program Pengajaran Bahasa Indonesia SLTP. Jakarta: Depdikbud.

Depdiknas. (2002). Membaca. Bahan pelatihan terintegrasi Berbasis Kompetensi Guru Mata Pelajaran Bahasa Indonesia. Jakarta: Dirjen Dikdasmen.

Depdiknas. (2003). Kurikulum 2004. Jakarta: Depdiknas.

Depdiknas. (2003). Pedoman khusus Pengembangan silabus dan Penilaian. Jakarta. Depdiknas.

Eanes, Robin. (1997). Content Area Literary: Teaching for Today and Tomorrow. Albany, NY: Delmar Publisher.

Harris, Larry \& Smith Carl B. (1986). Reading Instruction, Diacnostic Teaching in the Class Room. New York. MacMillan Publishing Company.

Lade, Robert. (1964). Language Testing The Construction and Use The Foreign Language Test. New York: Me Graw Hill Book Co.

Mulyasa. (2004). Kurikulum Berbasis Kompetensi MI (Madrasah Ibtidaiyah). Bandung: Remaja Rosdkarya.

Pamfrey. (1977). PD Measuring Reading Ability: Conceps, Sources, and Aplication. London: Hodder and Stoughton,

Robin, Dorthy. (1993). Teaching Elementary Language Art An Integrated Approach. Boston: Allyn and Bacon.

Sidi, Idra Djati. (2001). Menuju Masyarakat Belajar. Jakarta: Paramadina.

Syafi'ie. (1993). Terampil Berbahasa Indonesia I. Jakarta: Depdiknas.

Tompkins, Gail E. \& Hoskisson. (1991). Language Art Content and Teaching Strategis. New York: McMillan College Publisher. 